\title{
MODIFIED DISPERSIVE LIQUID-LIQUID MICROEXTRACTION USING GREEN SOLVENT FOR DETERMINATION OF POLYCYCLIC AROMATIC HYDROCARBONS (PAHS) IN VEGETABLE SAMPLES
}

\author{
(Pengekstrakan Mikro Cecair-cecair Serakan yang Terubahsuai dengan Pelarut Hijau untuk \\ Penentuan Polisiklik Aromatik Hidrokarbon (PAHs) dalam \\ Sampel Sayur - Sayuran) \\ Chai Mee $\operatorname{Kin}^{1}{ }^{*}$, Premla Devi Chander ${ }^{2}$, Wong Ling Shing ${ }^{3}$ \\ ${ }^{1}$ Department of Civil Engineering, College of Engineering \\ ${ }^{2}$ College of Graduate School \\ Universiti Tenaga Nasional, 43000 Kajang, Selangor, Malaysia \\ ${ }^{3}$ Faculty of Science, Technology, Engineering \& Mathematics, \\ INTI International University, 71800 Nilai, Negeri Sembilan, Malaysia \\ *Corresponding author: mkchai@uniten.edu.my
}

Received: 9 August 2015; Accepted: 11 December 2015

\begin{abstract}
According to International Agency for Research on Cancer (IARC), most of Polycyclic Aromatic Hydrocarbons (PAHs) known as genotoxic human carcinogen and mutagenic. PAHs represent as poorly degradable pollutants that exist in soils, sediments, surface water and atmosphere. A simple, rapid and sensitive extraction method termed modified Dispersive Liquid-Liquid Microextraction (DLLME) using green solvent was developed to determine PAHs in vegetable samples namely radish, cabbage and cucumber prior to Gas Chromatography Flame Ionization Detection (GC-FID). The extraction method is based on replacing chlorinated organic extraction solvent in the conventional DLLME with low toxic solvent, 1-bromo-3-methylbutane without using dispersive solvent. Several experimental factors such as type and volume of extraction solvents, extraction time, confirmation of $12 \mathrm{PAHs}$ by GC-MS, recovery percentages on vegetable samples and the comparative analysis with conventional DLLME were carried out. Both DLLME were successfully extracted 12 types of PAHs. In modified DLLME, the recoveries of the analytes obtained were in a range of $72.72-88.07 \%$ with RSD value below $7.5 \%$ which is comparable to the conventional DLLME. The use of microliter of low toxic extraction solvent without addition of dispersive solvent caused the method is economic and environmental friendly which is fulfill the current requirement, green chemistry based analytical method.
\end{abstract}

Keywords: polycyclic aromatic hydrocarbons, modified dispersive liquid-liquid microextraction, gas chromatography flame ionization detection

\begin{abstract}
Abstrak
Menurut agensi antarabangsa bagi penyelidikan kanser (IARC), kebanyakan Polisiklik Aromatik Hidrokarbon (PAHs) dikenali sebagai karsinogen genotoksik terhadap manusia dan mutagen. PAHs mewakili sebagai pencemar degradasi rendah yang wujud dalam tanah, enapan, air permukaan dan atmosfera. Satu kaedah pengekstrakan yang mudah, pantas dan sensitif yang digelar sebagai pengekstrakan mikro cecair - cecair serakan (DLLME) yang terubahsuai dengan pelarut hijau telah dibangunkan bagi penentuan PAHs dalam sampel sayur - sayuran iaitu lobak, kubis dan timun sebelum diukur menggunakan gas kromatografi pengesan nyala pengionan (GC-FID). Kaedah pengekstrakan ini adalah berdasarkan penggantian pelarut pengekstrakan organik berklorin di dalam DLLME konvensional dengan pelarut rendah toksik, 1-bromo-3-metilbutana tanpa menggunakan pelarut penyebar. Beberapa factor eksperimen seperti jenis dan isipadu pelarut pengekstrakan, masa pengekstrakan, pengesahan 12
\end{abstract}




\section{Chai et al: MODIFIED DISPERSIVE LIQUID-LIQUID MICROEXTRACTION USING GREEN SOLVENT FOR DETERMINATION OF POLYCYCLIC AROMATIC HYDROCARBONS (PAHS) IN VEGETABLE SAMPLES}

PAHs dengan GC-MS, peratusan perolehan semula sampel sayur - sayuran dan perbandingan analisis dengan DLLME konvensional telah dijalankan. Kedua - dua teknik DLLME telah berjaya mengekstrak 12 jenis PAHs. Bagi DLLME terubahsuai, perolehan semula analit berada dalam julat $72.72-88.07 \%$ dengan nilai RSD adalah kurang daripada $7.5 \%$ iaitu setanding dengan teknik DLLME konvensional. Penggunaan mikroliter pelarut pengekstrakan yang rendah toksik tanpa penambahan pelarut penyebar menyebabkan kaedah ini ekonomik dan mesra alam yang memenuhi keperluan semasa iaitu kaedah analisis berasaskan kimia hijau.

Kata kunci: polisiklik aromatik hidrokarbon, pengekstrakan mikro cecair-cecair serakan yang terubahsuai, gas kromatografipengesan nyala pengionan

\section{Introduction}

Polycyclic aromatic hydrocarbon (PAH) is a complex mixture of an end product, resulted from incomplete combustion of organic materials. It represents as poorly degradable pollutants that exist in soil, sediments, surface water and atmosphere [1]. Sixteen PAHs have been classified as genotoxic human carcinogen and mutagenic by the International Agency for Research on Cancer (IARC) and selected by US Environmental Protection Agency (EPA) as Constant Degree priority pollutants for regulatory process [2]. They are anthracene, fluoranthene, pyrene, benzo(b)fluoranthene, benzo(k)fluoranthene, acenaphthylene, acenaphthene, benzo(a)anthracene, benzo(a)pyrene, benzo(g,h,i)perylene, chrysene, cyclopenta(c,d)pyrene, dibenz(a,h)anthracene, dibenzo(a,l)pyrene, indeno(1,2,3c,d)pyrene and 5-methylchrysene.

To assess the penetration of PAHs or their metabolites in the plant, it is important to develop a sensitive, rapid, simple, economic and environmental friendly extraction method. Various conventional extraction methods such as Liquid-liquid extraction (LLE) and Solid-phase extraction (SPE) have been implemented [3]. However, the presences of various plant pigments and the limitations of conventional extraction method lead to the failure of developing a compatible, efficient, economical and miniaturize extraction method. The discovery of Dispersive Liquid-Liquid Microextraction (DLLME) method by Assadi and teammates solved the drawbacks of conventional method and it is known to be rapid and low cost method [4]. In this procedure, the mixture of extraction solvent and dispersive solvent is rapidly injected into aqueous sample results the formation of fine droplets. These droplets increase the surface area between extraction solvent and sample solution and speed up the extraction [2, 4]. However, there are few drawbacks on this method as it acquired toxic halogenated solvents used as extraction solvent and dispersive solvent. DLLME also restricts implication on vegetable matrices due to interferences [5].

In this study, modified DLLME was developed to determine the PAHs from the vegetable samples followed by gas chromatography-flame ionization detector (GC-FID). In this procedure, only minimal amount (100 $\mu 1)$ of low toxic extraction solvent is added into the vegetable sample compared to that two types of solvent (e.g. water immisicble and water miscible solvent) are needed in original DLLME to form the emulsion consist of fine droplets.

\section{Reagents and Materials}

\section{Materials and Methods}

Twelve types of PAHs (acenaphthylene, acenaphthene, fluorene, anthracene, phenanthrene, fluoranthene, pyrene, benzo(a)anthracene, chrysene, benzo(b)fluoranthene, benzo(k)fluoranthene and benzo(a)pyrene) were purchased from Supelco. 1-bromo-3-methylbutane, hexanol, heptanol, octanol, nonanol were purchased from Sigma-Aldrich. Acetone and Acetonitrile (HPLC Grade) were obtained from Merck. Deionised water (D.I.) was purified on a Milli$\mathrm{Q}$ water system. Stock solution of PAH standards were prepared by dissolving PAHs standard at $10 \mathrm{ppm}$ in acetonitrile. Working standard solutions of 12 types of PAHs were prepared in acetonitrile at concentration of 5 $\mathrm{ppm}$ to $0.1 \mathrm{ppm}$. The solutions were stored at $4{ }^{\circ} \mathrm{C}$ in a refrigerator. Vegetables namely radish (Raphanus sativus), cucumber (Cucumis sativus) and cabbage (Brassica oleracea) were purchased from the local organic market. The vortex agitator model no. VELP Scientifica $\mathrm{ZX}^{3}$ (Usmate, Italy) and the centrifuger with a model no. Hettich ROTOFIX 32 Benchtop centrifuge (Tuttlingen, Germany) were used in this experiment.

\section{Instrumentation}

The chromatographic analysis was performed by using Gas Chromatography model Agilent 7890A equipped with a split/splitless injection inlet, flame ionization detector (FID) and a 7683 automatic liquid sampler. The optimization 
of gas chromatography (GC-FID) condition was carried out and set up in which runtime of a sample requires 25 minutes. The 12 PAH compounds were separated by using HP-5 (5\% phenyl-methylpolysiloxane) capillary column ( $30 \mathrm{~m} \times 320 \mu \mathrm{m} \times 0.25 \mu \mathrm{m})$. The optimum condition of the GC-FID for separation of 12 PAHs was oven temperature commenced at $100^{\circ} \mathrm{C}$ for $1 \mathrm{~min}$ and was raised by $15^{\circ} \mathrm{C} \mathrm{min}^{-1}$ to $280{ }^{\circ} \mathrm{C}$ for 10 mins. Helium as carrier gas in a constant flow of $1 \mathrm{~mL} \mathrm{~min}^{-1}$, injector temperature of $290^{\circ} \mathrm{C}$ and in splitless mode.

Gas Chromatography-Mass spectrometry (GC-MS Shidmazu QP2010) was used to perform the confirmation of 12 types of PAH. The applied column comprises of $30 \mathrm{~m} \times 0.25 \mathrm{~mm}$ i.d. x $0.25 \mu \mathrm{m}$ firm thickness known as DB-5MS. The injection for analyte separation was made in splitless mode, injector temperature was maintained at $290^{\circ} \mathrm{C}$ and the injection volume was $1 \mu \mathrm{L}$. Ultra-pure helium gas (99.9995\%) was used as carrier gas with flow rate of $1.2 \mathrm{~mL}$ $\min ^{-1}$. The oven temperature programmed, where the initial temperature was $100^{\circ} \mathrm{C}$ and held for $1 \mathrm{~min}$ and ramp to $290{ }^{\circ} \mathrm{C}$ at $15^{\circ} \mathrm{C} \mathrm{min}^{-1}$ and held for 20 minutes. Total run time was $33.67 \mathrm{~min}$.

\section{Sample Preparation}

The vegetable sample was weighed, homogenized, centrifuged, filtered and spiked at $50 \mu \mathrm{L}$ of $10 \mathrm{ppm}$ of mixture of individual standard. The homogenized sample $(5 \mathrm{ml})$ was transferred into conical centrifuge tube.

An appropriate amount of extraction solvent (e.g. $100 \mu \mathrm{L}$ ) was added into the sample and gently shaken. A cloudy solution formed due to tiny droplets of extraction solvent dispersing in the sample solution. After homogenization (vortex) and centrifugation process at rate of $3000 \mathrm{rpm}$ for 10 minutes, the sedimented layer formed at bottom of the conical tube. The sediment layer further transferred into the glass insert in a $2 \mathrm{ml}$ of vial using of microsyringe. $1 \mu \mathrm{L}$ of the sediment solution was injected into GC-FID using autosampler for the analysis at optimized GC-FID condition. Three replicates were done for each trial.

\section{The Selection of Extraction Solvent}

The selection of an extraction solvent is crucial for the determination of extraction efficiency of the modified method. Five types of low toxic solvents namely hexanol, heptanol, octanol, nonanol and 1-bromo-3methylbutane have been tested to obtain an optimal extraction solvent. The selection of low toxic extraction solvent was made based on few criteria's. The extraction solvent must be (a) high density than water, (b) low solubility in water, (c) achieves high percentage recovery of target analyte and (d) achieve good chromatographic behaviour. Besides, the toxicity level of the selected extraction solvent must be less hazardous compared with conventional DLLME extraction solvent (e.g. tetrachloroethylene, chloroform, chlorobenzene) and also an environmental friendly solvent in order to achieve the aim of green chemistry. The behaviour of toxicity and solubility in water of two conventional DLLME extraction solvents (tetrachloroethylene and chlorobenzene) and five selected extraction solvents (hexanol, heptanol, octanol, nonanol and 1-bromo-3methylbutane) are tabulated in Table 1. Among all the tested solvents, 1-bromo-3-methylbutane has lowest toxicity and lowest solubility in water.

Table 1. Lethal Dose $\left(\mathrm{LD}_{50}\right)$ Toxicity of 7 types of Extraction Solvents

\begin{tabular}{llccc}
\hline No & Extraction Solvent & $\mathrm{LD}_{50(\mathrm{mg} / \mathrm{kg}, \text { oral })}$ on rat & Solubility in water & Ref. \\
\hline 1 & Tetrachloroethylene & $2600 / 2629$ & $206 \mathrm{mg} / \mathrm{L}$ at $25^{\circ} \mathrm{C}$ & {$[6]$} \\
2 & Chlorobenzene & $1437-3400$ & $400 \mathrm{mg} / \mathrm{L}$ at $20^{\circ} \mathrm{C}$ & \\
3 & Hexanol & 720 & $5000 \mathrm{mg} / \mathrm{L}$ at $20^{\circ} \mathrm{C}$ & \\
4 & Heptanol & 500 & $2850 \mathrm{mg} / \mathrm{L}$ at $100^{\circ} \mathrm{C}$ & \\
5 & Octanol & 5000 & $1000 \mathrm{mg} / \mathrm{L}$ at $20^{\circ} \mathrm{C}$ & \\
6 & Nonanol & 3.56 & $1000 \mathrm{mg} / \mathrm{L}$ at $20^{\circ} \mathrm{C}$ & \\
7 & 1-Bromo-3-methylbutane & 6150 & $196 \mathrm{mg} / \mathrm{L}$ at $16.5^{\circ} \mathrm{C}$ & \\
\hline
\end{tabular}




\section{Chai et al: MODIFIED DISPERSIVE LIQUID-LIQUID MICROEXTRACTION USING GREEN SOLVENT FOR DETERMINATION OF POLYCYCLIC AROMATIC HYDROCARBONS (PAHS) IN VEGETABLE SAMPLES}

The percentage of recovery (\%) calculated based on the ratio of the concentration of peak area after extraction to the initial spiked concentrations of analyte in the sample solution.

\section{Results and Discussion}

Experimental parameters for the modified DLLME, including the types of low toxic solvent and its volume as well as the extraction time were optimized. From the Figure 1,1-bromo-3-methylbutane yield the highest average recovery percentage $(75.53 \%)$ compare to other extraction solvents. Meanwhile, other extraction solvents failed to obtain the acceptable recovery range $(70-120 \%)$ set up by the International Conference on Harmonisation (ICH) on the validation of analytical procedures [7]. 1-bromo-3-methylbutane solvent was able to extract all the desired analytes well in the acceptable recovery range from the liquid matrices. Therefore it was ideal to select 1-bromo-3-methylbutane solvents as an extraction solvent in modified DLLME on the extraction of 12 PAHs in vegetable samples. Other four extraction solvents (hexanol, heptanol, octanol and nonanol) have the low recovery percentages. This may due to they are high solubility in water which exposed to the interferences that presence in water and caused the solvents loss interaction with analytes as $12 \mathrm{PAHs}$ are immisible in water. Besides, these four extraction solvents are less dense $(0.8$ $\mathrm{g} / \mathrm{mL}$ ) than water leaded the failure of the formation of sedimented extraction phase. The droplets formation of extraction solvent floats on the surface of the sample solution causes the difficulties to extract the analytes from the sample solution. These are prove that the density of the solvent and its solubility in water are the important criteria's when selecting the extraction solvent as mentioned above.

Results showed that the sedimented extraction phase obtained is depending on the amount of extraction solvent used. The higher volume of extraction solvent used the larger amount of sedimented phase was obtained. However, the aim of the study is to find out the minimal usage of extraction solvent to extract all 12 PAHs. In fact, $50 \mu \mathrm{L}$ of the extraction solvent produced minimal amount of sediment layer and caused the difficulties to transfer the sediment layer into the vial as the sediment layer was mixed up with the sample precipitate even though after long period of centrifugation process. In order to reduce the solid matrix interference problem, $100 \mu \mathrm{L}$ was selected as an ideal volume as the study focuses on the minimal usage of solvent upon extracting 12 PAHs from solid matrices.

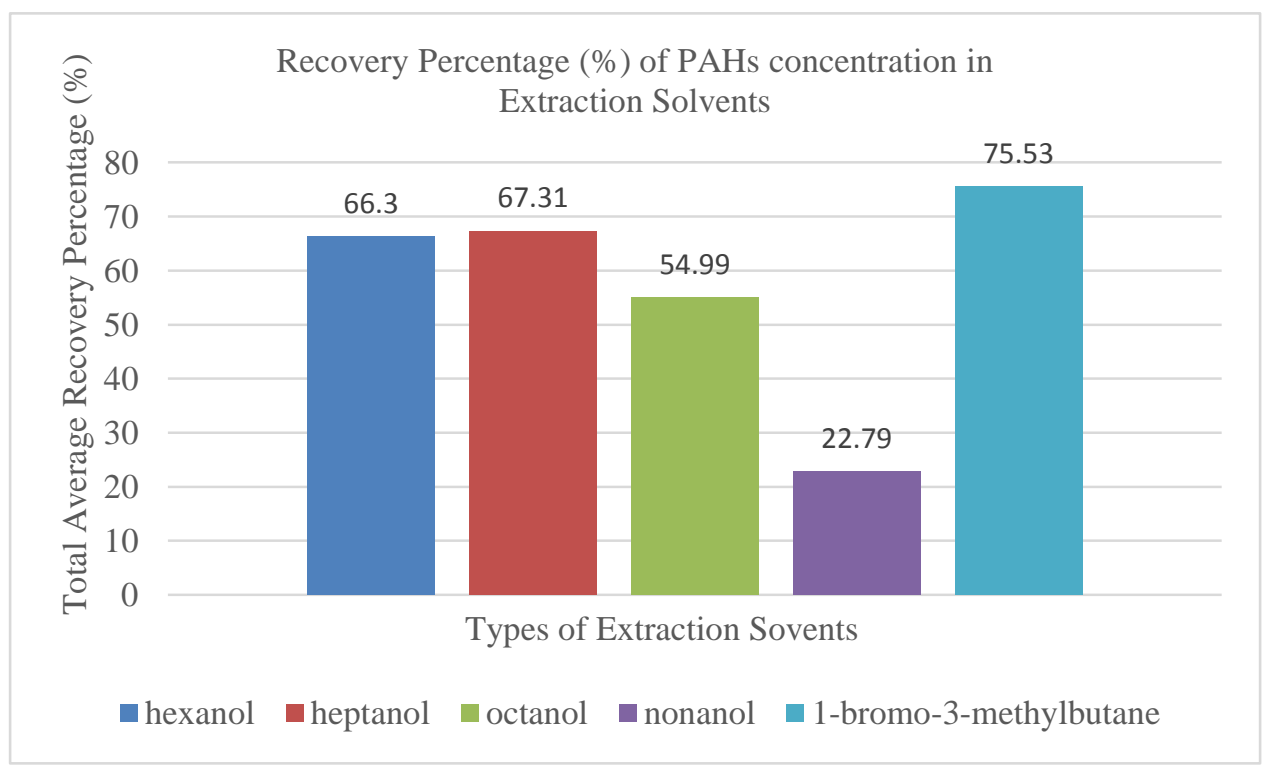

Figure 1. Recovery Percentage (\%) of PAHs concentration in extraction solvents 


\section{Extraction time}

In conventional DLLME, fine droplets of organic solvent are formed in the sample solution with the mixture of extraction solvent and dispersive solvent [8]. This may due to the quick mass transfer of analytes from the aqueous phase to the extraction solvent. Meanwhile in modified DLLME, homogenous fine droplets were formed reproducibly with aid of gentle shaken without addition of dispersive solvent. The extraction time is defined as shaking time. The results showed that there was no significant difference in the extraction recoveries for all the PAHs during the shaking time range $(1,2,4,6,8$ and 10 minutes). Since the extraction recovery with extraction time of $2 \mathrm{~min}$ lies within the acceptable range (70 to $120 \%)$ with the low relative standard deviation $(<5 \%), 2 \mathrm{~min}$ shaking time was considered as optimal time for modified DLLME. Short extraction time required in modified DLLME is one of the most remarkable advantages of modified DLLME.

\section{Confirmation of 12 PAHs by GC-MS}

The mass spectrometry detector can be used for detection and identification purpose as well as for quantitation of analytes. In this study, gas chromatography couple with mass spectrometry detector was implemented only for analyte identification and confirmation. The sediment extraction phase was withdrawn and injected into GC-MS for full scan analysis. The total ion chromatogram of the target analytes under optimized GC-MS conditions was obtained and shown in Figure 2.

In MS full scan mode, all ions produced from each analyte peak in the MS was employed in confirmation of the targeted analytes. High reliability of identification was achieved by making comparison of the MS of the targeted analyte at the top of its chromatographic peak with the best matching compound in the standard mass-spectral libraries. From the results, it was known that all the 12 types of PAHs were successfully extracted using modified DLLME. The 12 types of PAHs were successfully identified and confirmed to be present in the sedimented extraction phase. The initial ion fragments for the first peak were formed at 7.27 minutes and ends at 18.604 minutes. The range of the ion fragments forms between $152.10 \mathrm{~m} / \mathrm{z}$ to $276.15 \mathrm{~m} / \mathrm{z}$. The existing of molecular ions with highest $\mathrm{m} / \mathrm{z}$ ratio similar to their respective molecular weight was shown to present in individual PAHs mass spectrum.

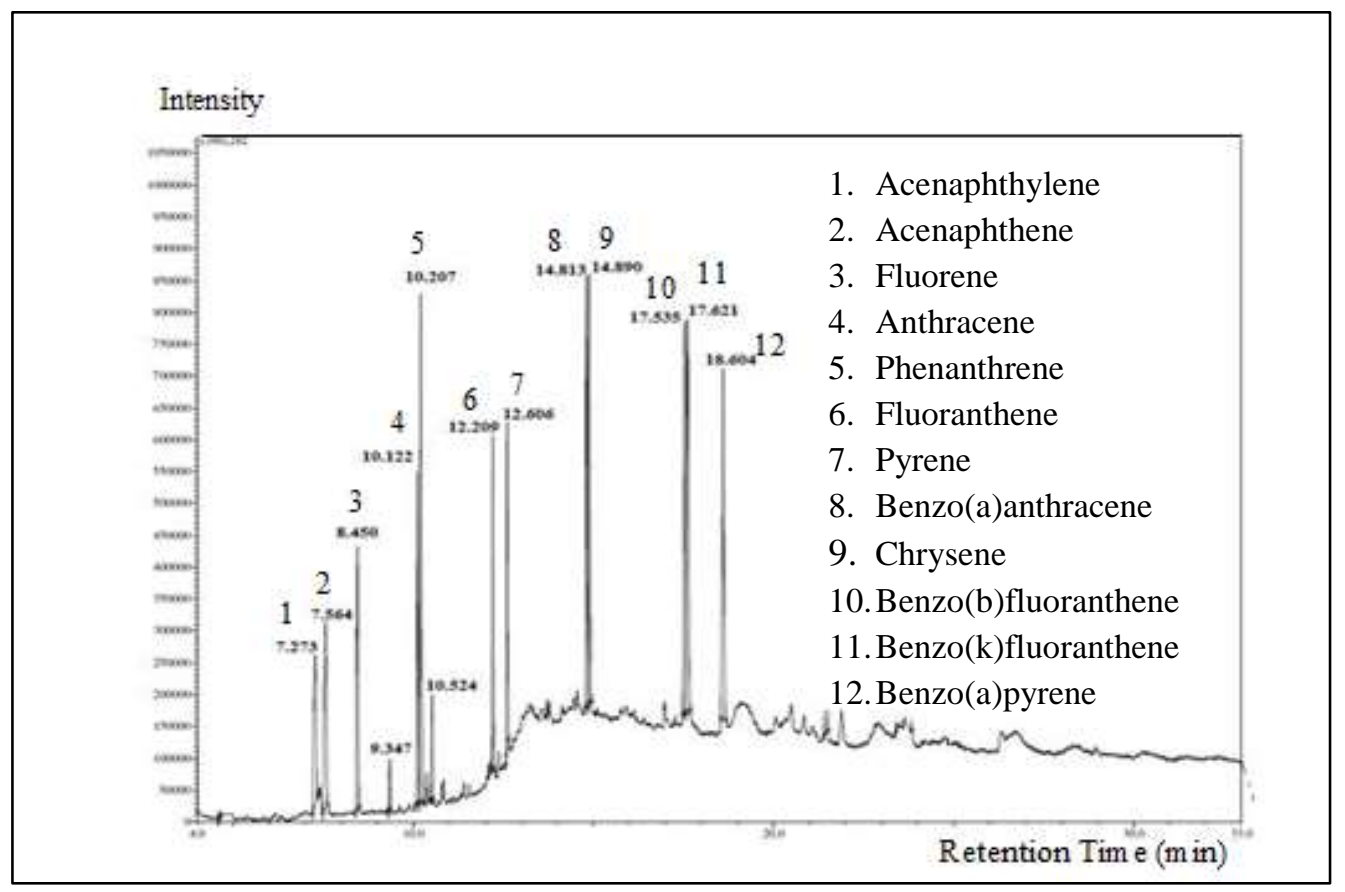

Figure 2. Chromatogram of 12PAHs obtained from modified DLLME in GC-MS Full Scan Mode 


\section{Chai et al: MODIFIED DISPERSIVE LIQUID-LIQUID MICROEXTRACTION USING GREEN SOLVENT FOR DETERMINATION OF POLYCYCLIC AROMATIC HYDROCARBONS (PAHS) IN VEGETABLE SAMPLES}

\section{Comparison between Modified DLLME and Conventional DLLME}

The modified DLLME was compared with conventional DLLME using the same three types of vegetable (e.g. radish, cabbage and cucumber). The purpose of this comparison is to determine the efficiency of the modified DLLME towards the vegetable matrix compared to the conventional DLLME. In conventional DLLME, the common implemented extraction solvent was tetrachloroethylene at $50 \mu \mathrm{L}$ and the dispersive solvent was acetone at $100 \mu \mathrm{L}$. In modified DLLME, 1-bromo-3-methylbutane was used as extraction solvent at $100 \mu \mathrm{L}$ and there is no addition of dispersive solvent. Each sample was injected three times and the recovery percentage and RSD value of both methods on three vegetable samples were calculated and tabulated in Table 2.

Table 2. Comparison of Recovery Percentage (\%) of Modified DLLME with Conventional DLLME in the vegetable samples

\begin{tabular}{|c|c|c|c|c|c|c|}
\hline \multirow[b]{2}{*}{ РАH } & \multicolumn{2}{|c|}{ Radish } & \multicolumn{2}{|c|}{ Cucumber } & \multicolumn{2}{|c|}{ Cabbage } \\
\hline & $\begin{array}{c}\text { Modified } \\
\text { DLLME } \\
(\%) \\
\text { (RSD\%) }\end{array}$ & $\begin{array}{c}\text { Conven. } \\
\text { DLLME } \\
(\%) \\
(\text { RSD\%) }\end{array}$ & $\begin{array}{c}\text { Modified } \\
\text { DLLME } \\
(\%) \\
\text { (RSD\%) }\end{array}$ & $\begin{array}{c}\text { Conven. } \\
\text { DLLME } \\
(\%) \\
(\text { RSD\%) }\end{array}$ & $\begin{array}{c}\text { Modified } \\
\text { DLLME } \\
(\%) \\
(\text { RSD\%) }\end{array}$ & $\begin{array}{c}\text { Conven. } \\
\text { DLLME } \\
(\%) \\
(\text { RSD\%) }\end{array}$ \\
\hline Acenaphthylene & $83.05(0.1)$ & $76.83(0.3)$ & $85.29(1.1)$ & $82.35(3.2)$ & $80.47(3.5)$ & $75.64(4.5)$ \\
\hline Acenaphthene & $87.88(0.2)$ & $86.48(0.2)$ & $81.94(4.0)$ & $78.32(6.7)$ & $78.18(2.7)$ & $76.26(3.1)$ \\
\hline Fluorene & $88.07(0.5)$ & $80.39(1.8)$ & $80.26(3.0)$ & $79.92(4.2)$ & $76.67(3.5)$ & 74.35 (3.9) \\
\hline Anthracene & $82.14(0.6)$ & $77.27(1.7)$ & $76.40(3.7)$ & $73.43(3.8)$ & $77.96(2.7)$ & $72.50(2.8)$ \\
\hline Phenanthrene & $81.81(0.4)$ & $76.36(1.8)$ & $75.64(3.4)$ & $71.89(5.0)$ & $76.29(3.2)$ & $71.64(3.8)$ \\
\hline Fluoranthene & $78.02(0.3)$ & $74.24(2.3)$ & $78.53(2.1)$ & $74.35(4.1)$ & $77.86(1.9)$ & $74.11(2.7)$ \\
\hline Pyrene & $78.68(3.3)$ & $72.65(2.5)$ & $77.29(7.5)$ & $75.90(7.7)$ & $75.08(0.6)$ & $72.60(0.7)$ \\
\hline Benzo(a)anthracene & $77.18(0.5)$ & $75.41(4.0)$ & $74.37(7.1)$ & $71.13(7.4)$ & $74.23(4.4)$ & $73.08(4.6)$ \\
\hline Chrysene & $75.79(0.2)$ & $73.85(3.9)$ & $78.52(5.1)$ & $75.76(6.0)$ & $74.61(1.5)$ & $70.44(1.8)$ \\
\hline Benzo(b)fluoranthene & 80.94 (1.9) & $75.64(4.7)$ & $74.68(3.3)$ & $72.50(3.4)$ & $75.56(3.6)$ & $73.81(4.6)$ \\
\hline Benzo(k)fluoranthene & $75.38(3.1)$ & $71.34(4.7)$ & $73.05(3.0)$ & $71.28(5.3)$ & $74.25(2.6)$ & $70.36(3.9)$ \\
\hline Benzo(a)pyrene & $72.72(0.9)$ & $71.93(5.0)$ & $72.45(6.2)$ & $70.59(6.5)$ & $75.62(2.8)$ & $71.08(3.4)$ \\
\hline
\end{tabular}

From the results obtained, both methods successfully extracted all the 12 PAHs from the respective vegetables. However, modified DLLME yielded higher recovery percentages ranged from $72.72 \%$ to $88.07 \%$ in radish, 72.45 $\%$ to $85.29 \%$ in cabbage and $74.23 \%$ to $80.47 \%$ in cucumber with minimal of RSD values from $0.1 \%$ to $7.5 \%$ compared to the conventional DLLME that yielded the recovery percentages ranged from $71.34 \%$ to $86.48 \%$ in radish, $70.59 \%$ to $82.35 \%$ in cabbage and $70.36 \%$ to $76.26 \%$ in cucumber with RSD values (\%) from $0.2 \%$ to 7.7 $\%$.

1-bromo-3-methylbutane has higher density than water and low solubility in water leads to high extraction efficiency compared to tetrachloroethylene which used as extraction solvent in conventional DLLME. Without the addition of dispersive solvent, 1-bromo-3-methylbutane capable of forming the fine droplets and enhances the contact surface area between analyte and extraction solvent whereas chlorosolvents acquired dispersive solvent to extract the analyte (12 PAHs) from the vegetable sample. Low recovery of tetrachloroethylene in conventional DLLME may due to the low solubility of tetrachloroethylene towards the analyte [9]. 


\section{Conclusion}

A novel sample preparation method designated as Modified DLLME has been developed for the determination of PAHs in vegetable samples with only using minimal amount of low toxic solvent as extraction solvent without addition of dispersive solvent. Compared to conventional DLLME, modified DLLME yields higher efficiency recovery range from $72.72-88.07 \%$ at minimal RSD value range from $0.1-7.5 \%$. Thus modified DLLME is a reliable alternative technique for sample pre-concentration in terms of performance and speed. Major advantages of this modified method are present at low cost and only usage of minimal amount of low toxic extraction solvent to form fine droplets. This method was applied on solid matrices as conventional DLLME majorly focused on the liquid matrices due to the inteference problems.

\section{Acknowledgement}

The authors express special thanks to the Ministry of Higher Education of Malaysia - Fundamental Research Grand No. FRGS/1/2013/ST01/UNITEN/02/1 for the financial supports, UNITEN Renewable Energy Centre and Faculty Science of University Malaya for the laboratory analysis.

\section{References}

1. Mohammadi, V. K., Mohammadi, A., Hashemi, M., Khaskar, R. and Haratian, P. (2012). Microwave-assisted extraction and dispersive liquid-liquid microextraction followed by gas chromatography-mass spectrometry for isolation and determination of polycylic aromatic hydrocarbons in smoked fish. Journal of Chromatography A, 1237: $30-36$.

2. Hosseini, M. H., Mohamad, R., Akbarian, S., Mizani, F., Pourjavid, R. M. and Arabieh, M. (2013). Homogeneous liquid-liquid microextraction via floatation assistance for rapid and efficient determination of polycyclic aromatic hydrocarbons in water samples. Analytica Chimica Acta, 762: 54 - 60.

3. Tseng, W. C., Chen, S. P. and Huang, S. D. (2014). Optimization of two different dispersive liquid-liquid microextraction methods followed by gas chromatography-mass spectrometry determination for polycyclic aromatic hydrocarbons (PAHs) analysis. Talanta, 120: $425-432$.

4. Leong, M. I., Chang, C. C., Fuh, M. R. and Huang, S. D. (2010). Low toxic dispersive liquid liquid microextraction using halosolvents for extraction of polycyclic aromatic hydrocarbons in water samples. Journal of Chromatography A, 1217: 5455 - 5461.

5. Guo, L. and Lee, H. K. (2011). Low density solvent-based solvent demulsification dispersive liquid-liquid microextraction for the fast determination of trace levels of sixteen priority polycyclic aromatic hydrocarbons in enviromental water samples. Journal of Chromatography, A, 1218: 5040-5046.

6. Chemical Properties of Product. (2008). Access online from Chemical e-Book: http://www.chemicalbook.com/ProductChemicalPropertiesCB1394458_EN.html. Retrieved 15/8/2014.

7. Chai, M. K. and Tan, G. H. (2009). Validation of a headspace solid-phase microextraction with an internal standard method for the determination of pesticide residues in fruits and vegetables. Food Chemistry 117: 561 567.

8. Zang, X. H., WU, Q. H., Zhang, M. Y., XI, G. H. and Wang, Z. (2009). Developments of Dispersive LiquidLiquid Microextraction Technique. Chinese Journal of Analytical Chemistry, 37(2): 161 - 168.

9. Zgola-Grzekowiak, A. and Grzeskowiak, T. (2011). Dispersive Liqiud-Liqiud Microextraction. Trends In Analytical Chemistry, 30(9): 1382 - 1397. 